\title{
A Google Trends Analysis: Change in internet searches related to cardiovascular disease during COVID-19 outbreak
}

\author{
Yakup Alsancaka, Murat Gul \\ a Department of Cardiology, Meram School of Medicine, Necmettin Erbakan University, Konya, Turkey \\ ${ }^{b}$ Department of Cardiology, Aksaray University School of Medicine, Aksaray, Turkey
}

\section{ARTICLE INFO}

Article history:

Submitted: 19. 6. 2020

Accepted: 18. 7. 2020

Available online: 1. 12. 2020

Kličová slova:

COVID-19

Google

Internet

Srdeční onemocnění
SOUHRN

Cíl: Rychle přibývající informace o koronaviru (COVID-19) se pravidelně šǐrí na webových stránkách i na sociálních sítích. Zkoumali jsme trendy v zadávání vyhledávacích dotazů na webové stránce společnosti Google, které se týkaly témat kardiovaskulární onemocnění nebo jejich symptomy, jako jsou bolest na hrudi, hypertenze, hyperlipidemie a infarkt myokardu v období pandemie COVID-19, v Turecku a Itálii, tedy ve dvou zemích nejvíce postižených tímto onemocněním.

Metody: K získání údajů o vyhledávacích aktivitách uživatelů internetu a o základních typech dotazů ve vyhledávači Google byl použit nástroj Google Trends ${ }^{T M}\left(\mathrm{GT}^{\mathrm{T}}\right)$. Pátrali jsme po nejznámějších klíčových slovech souvisejících s kardiovaskulárními onemocněními a jejich symptomy, jako jsou bolest na hrudi, infarkt myokardu, srdeční onemocnění, hypertenze a vysoké hodnoty cholesterolu, použitými v období mezi 1. lednem a 5. květnem 2020 v nástroji GTTM, přičemž dotazy byly zadávány v turečtině a italštině.

Výsledky: Zdálo se, že zájem o témata související s koronavirem v Turecku a Itálii roste a po krátké době mírně opadá. Mezi lednem a květnem 2020 bylo možno v obou zemích pozorovat větší trend ve vyhledávání otázek spojených s bolestí na hrudi, hypertenzí, inhibitory angiotenzin konvertujícího enzymu (ACEI) a úmrtím. Intenzita zadávaných dotazů na téma infarkt myokardu se celoročně neměnila, byl však pozorován nápadný pokles zájmu o hodnoty cholesterolu. Ukázalo se rovněž, že s přibývající délkou pandemie se intenzita vyhledávání v obou zemích snížila.

Závěr: Internet Ize využít ke studiu chování lidí podle jejich aktivity při vyhledávání různých otázek souvisejících s kardiovaskulárními onemocněními a jejich symptomy v době vypuknutí pandemie. Získané údaje dokazují, že uživatelé internetu v obou zemích se v průběhu pandemie COVID-19 intenzivně zajímali o otázky kardiovaskulárních onemocnění a s nimi souvisejícími symptomy.

(c) 2020, ČKS.

\section{ABSTRACT}

Aim: A rapidly grown up information about coronavirus (COVID-19) has been regularly broadcast on internet websites or social media. We investigated the Google research trends in searches regarding cardiovascular system diseases or symptoms such as chest pain, hypertension, hyperlipidemia, heart attack during the COVID-19 pandemic in two countries, Turkey and Italy, which are most affected by this disease.

Methods: The Google Trends ${ }^{\mathrm{TM}}$ ( $\mathrm{GT}^{\mathrm{TM}}$ ) was used to retrieve data on Internet user search activities and patterns of Google search queries. We searched most known keywords related to cardiovascular disease and symptoms such as chest pain, heart attack, heart diseases, hypertension, high cholesterol in GT ${ }^{\mathrm{TM}}$ between January 1, 2020 and May 5, 2020 in Turkish and Italian.

Results: Search interest about coronavirus in Turkey and Italy appeared to have an increasing pattern and it has gradually tended to fall after a short time. Searching trends were higher both of countries about chest pain, hypertension, ACE inhibitor and death between January and May 2020. Searching rates about heart attack was not different for all year, but a significant decrease was remarkable for cholesterol. It was also revealed that as the duration of the pandemic increases in both countries, these research rates decrease. Conclusion: Internet could be used to determine behaviours of people for searching cardiovascular disease and their symptoms during the outbreak. These data illustrate that internet users in both countries conducted an intense research on cardiac symptoms or diseases during the COVID-19 pandemic.
Keywords:

COVID-19

Google

Heart disease

Internet 


\section{Introduction}

Cardiovascular diseases are still the leading cause of mortality and morbidity worldwide. An estimated more than 17.6 million deaths per year in 2016 occurred and nearly $30 \%$ of worldwide deaths occured due to cardiovascular disease. ${ }^{1}$ For the last six months, a novel coronavirus infection as named Corona Virus Disease 2019 (COVID-19) and related deaths have an important area in the global agenda. On May 5th 2020 the World Health Organization (WHO) reported 3525116 confirmed cases with a $6 \%$ (243 545 death) cumulative mortality rate. Due to the worldwide detection of thousands of cases and widespread diffusion COVID-19 has become a remarkable issue for the whole world. Because of high virulence and spreading rate of the virus, curfews and strict social containment are imposed in many countries by calls to 'stay home' to slow the spread of the outbreak. During a quarantine, different stressors like that fear of infection, social distancing, information lacking may lead to a decline in patients' hospital admissions. Accordingly prior studies showed that there was a significantly reduction in ST-segment elevation cardiac catheterization labaratory activations in the United States and Spain during COVID 19 era. $^{2,3}$ It is particularly crucial to understand the reduction of patient-based hospital presentation as it can lead to a delay in treatment and devastating consequences. Therefore cardiac emergencies such as acute coronary syndromes (ACS), pulmonary embolism or acute abdomen etc. are puzzles waiting to be solved. The reasons of reduced rate of hospital admissions for ACS during COVID-19 outbreak and its possible chronic effects are the questions to be answered. ${ }^{4}$

In today's world internet and social media are a part of daily life. Due to easy and fast accessibility to information internet has become a great online library for health-care related issues. A continuous escalation of information related COVID-19 pandemic has been regularly broadcost in social media, so millions of people who are currently under lockdown all around the world are using the internet to search answers to their questions. Therefore, $72 \%$ of internet users access this information source using a search engine and 'Google' is the most popular one with $75 \%$ usage rate. ${ }^{5}$ Google Trends ${ }^{\mathrm{TM}}$ (Google Inc. Mountain View, CA, USA) is a product of Google for using to show frequency of searches items at specific time and location. ${ }^{6}$ The effectiveness of Google Trends ${ }^{\mathrm{TM}}$ (GTTM) as an epidemiological surveillance search engine has been proved in topics such as rhinitis, detecting influenza epidemics or global public interest in osteoarthritis. ${ }^{5,7,8}$ Currently, in a published study a positive correlation was demonstrated between frequency of searches for loss of smell information and COVID-19 infection. ${ }^{9}$ And also another study demonstrated that public interest is on average highest 11.5 days before the peak of infected cases during COVID-19 pandemic with using GTTM analysis. ${ }^{10}$

In the current study, we aim to investigate the Google research trends in searches regarding cardiovascular system diseases or symptoms such as chest pain, hypertension, hyperlipidemia, heart attack during the COVID-19 pandemic in two countries, Turkey and Italy, which are most affected by this disease.

\section{Methods and material}

\section{Google Trends}

The Google Trends ${ }^{\mathrm{TM}}$ which is a freely accessible statistical tool (https://trends.google.com/trends/) was used to retrieve data on internet user search activities and patterns of Google search queries. ${ }^{11}$ The search frequency of the requested data can be pulled from this internet application until 2004 and up to 36 hours before to the research. It must be taken into account that GTTM reports are not demonstrated as the total number of searches over time and refer to the absolute number of searches based on the total number of searches performed during the specified interest period. These numbers provided by Google are equal with relative search volumes (RSV) that values vary from 0 to 100 . Thus, a score of 100 represents the highest level of public interest in a specific search within a selected location or worldwide and time interval. A value of 50 means that the research item is half as popular compared with the top level. Likewise, the value 0 does not necessarily indicate no searches, its means the research item was less than $1 \%$ popular for searching. ${ }^{11,12}$

\section{Search strategy}

The majority of data were collected between January 1, 2020 and May 5, 2020 to show the effect of COVID-19 pandemic period with using the available GTTM. In order to reveal some variables more clearly, the last 12 months screening data were examined. We evaluated the results of the internet screening of people living in Turkey and Italy. Italy was chosen as the second country to evaluate, because of the daily situation of Italy during COVID-19 outbreak is closely followed by visiual and written media in Turkey. We searched most known keywords related to cardiovascular diseases and symptoms such as chest pain, heart attack, heart diseases, hypertension, high cholesterol in GTTM. We did not perform a specific search for 'dyspnea' due to well known symptom for COVID-19. This process was repeated with manual translation of the above search terms into Turkish and Italian (respectively, 'göğüs ağrısı', 'dolore al petto' and 'kalp krizi', 'infarto' and 'kalp hastalıkları', 'malattie cardiache' and 'hipertansiyon', 'ipertensione' and 'yüksek kolesterol', 'colesterolo alto'). And also we searched keywords 'death', 'coronavirus' and 'angiotensin converting enzyme inhibitors (ACE inhibitor)' to evaluate of public interest (respectively 'ölüm', 'morte' and 'corona, korona', 'coronavirus, nuovo coronavirus' and 'ACE inhibitörü', 'ACE-inibitore').

\section{Results}

Search interest about coronavirus in Turkey appeared to have an increasing pattern. On February 26th, two weeks before the first cases were announced, a public interest can see (29/100), and this trend shows its peak level on March 13th (two days after the first confirmed case) (WHO) and March 17th, after that date the popularity slowly waning up to this time. In Italy, search interest began on January 31st (19/100), but there is no increase until the February 21st (first confirmed case) (WHO) $(43 / 100)$. It reaches its peak on February 23 rd and after 


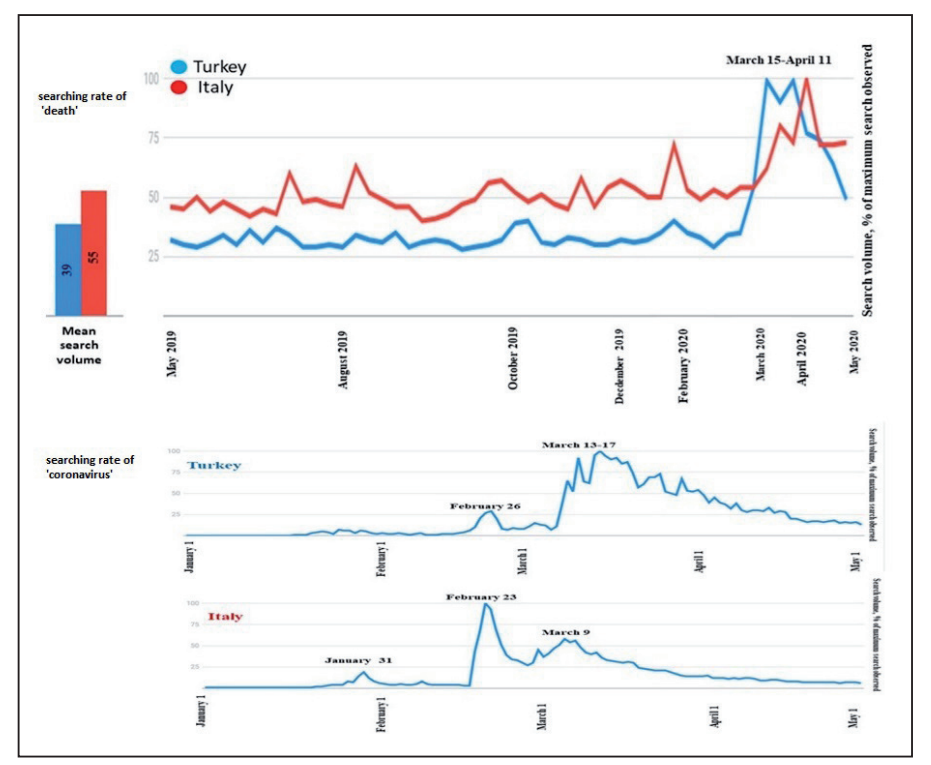

Fig. 1 - The figure demonstrates the searching result graphics of Google Trends ${ }^{\mathrm{TM}}$ for 'death' and 'coronavirus'.

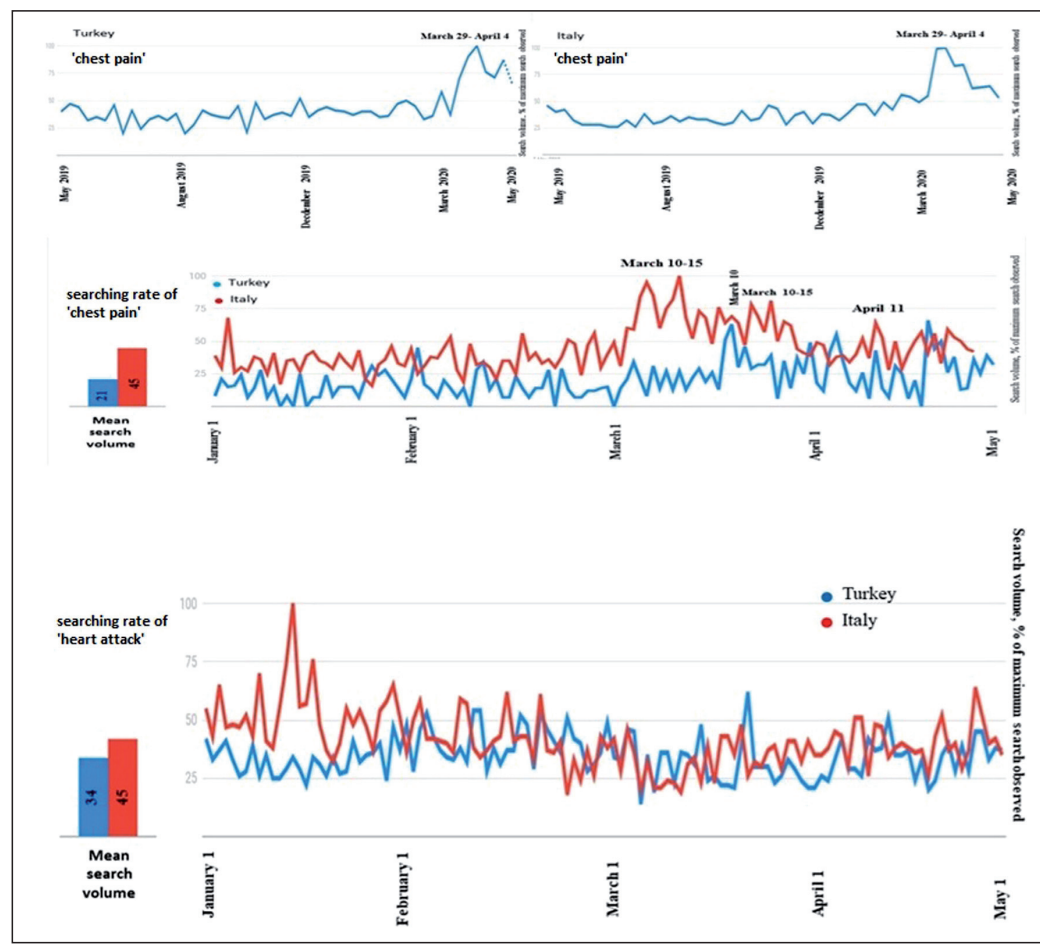

Fig. 2 - The figure demonstrates the searching result graphics of Google Trends ${ }^{T M}$ for 'chest pain' and 'heart attack'.

Fig. 3 - The figure demonstrates the searching result graphics of Google Trends ${ }^{\mathrm{TM}}$ for 'heart disease', 'cholesterol', 'hypertension' and 'angiotensin converting enzym inhibitors'. 
that day it has gradually tended to fall. Although internet searches about death in Italy have remained stable over the past one year, it tends to increase since the beginning of March and at the highest level between March 22nd and April 11th. There is a similar graphic for Turkey, but peak searches days are March 15th and April 4th. It is noteworthy that the number of searches is lower on the days when the higher number of deaths is specified according to WHO records. Internet searches based on heart disease of people, in generally both of two countries are similar with a fluctuating course. But in Turkey, there was a peak (100/100) for searching on March 21st. However, no significant difference has been observed in the searches related to heart attack for last five months. According to internet searches for chest pain, the graphic has remained normal in the last one year, while there was a significant increase in both countries in March 2020. And also periodic increases in internet researches for chest pain in both countries are remarkable in the last five months. For hypertension, while the level of interest is high in the normal time interval in both societies, peak values are observed in the screening rate in March 2020. Moreover, searching for ACE inhibitor volume is higher in March in both of two country. Finally, a remarkable decrease in cholesterol related screening has been observed since March 2020. Figures 1, 2 and 3 demonstrate the searching results and graphics of GTTM.

\section{Discussion}

These data illustrate that internet users in both countries conducted research on cardiac symptoms or diseases during the COVID-19 infection. It was also revealed that as the duration of the pandemic increases in both countries, these research rates decrease.

In line with the information provided through written, social and visual media or telecommunication systems about the COVID-19 infection, it can be considered that awareness is raised not only in healthcare professionals but almost in the whole society. The daily life has been affected in all its aspects during this pandemic and quarantine practices have been carried out in many countries and cities to limit the spread of the disease. And it should not be forgotten that other diseases, especially cardiovascular diseases are still an important health problem during this pandemic. Reporting the number of deaths daily in media and sharing images of different countries attract the attention of the society in Turkey. In the information age, digital inquiry has become an important step for epidemiological evaluation, especially with the increasing use of smartphones in daily. People's interaction increases with using social media, so it can be thought that the digital query rates are increasing. The use of digital internet resources and data has become an indispensable part in the field of health. Currently, GT ${ }^{T M}$ is the most popular tool in addressing health issues and topics with the use of internet data. ${ }^{12}$ In this context, some studies have been performed about cardiovascular disease with using GTTM. It has been shown that internet search volumes about cardiovascular disease seeking behaviour has a seasonal and geographic variation. ${ }^{13}$ An important cor- relation between Google search trends and prevalence of cardiovascular disease risk factors such as hypertension, smoking, and diabetes mellitus was shown in an another trial. ${ }^{14}$ Senecal et al. demonstrated a significant correlation online searches of 'chest pain' symptom with prevalance of cardiovascular disease and authors mentioned that internet search activities may be a new area for cardiovascular research and care. ${ }^{15}$ In addition, Platel et al. showed that hypertension occurs more in the winter months and the frequency of searching for the term 'hypertension' increases in internet browsing. ${ }^{16}$

In the light of this evidences, we aimed to evaluate the behaviors of people seeking basic and known cardiovascular system diseases and symptoms in both countries, Turkey and Italy, during COVID-19 pandemic. Accordingly, internet searches related to chest pain significantly increased in both countries in March 2020 compared to the last year. But, there has been no significant increase in searches related to 'heart attack' in the last 5 months. It is noteworthy that the term 'chest pain' is screened as 'coronavirus and chest pain'. In Turkey, we saw that the searching as 'heart disease' has a peak in March 2020. It might be the effect of emphasizing the fact that cardiovascular disease belongs to the chronic diseases and coronavirus related deaths are high in patients with heart disease in visual media in Turkey. In addition, it is observed that internet searches related to hypertension and ACE inhibitors, which are a group of antihypertensive drugs, peaked in March and April in the last five months in both countries. Discussing the studies about the potential relationship between the use of angiotensin-receptor blockers/angiotensin converting enzyme inhibitors and the risk of COVID-19 on media or intensive interaction network between people in the early period of pandemic may have increased the internet research rates of these drugs. In fact, this issue was also discussed among healthcare professionals and recommendations were published by some societies of cardiology. ${ }^{17}$ In Turkey, especially cardiologists often appeared in the evening television news bulletins, so it may have led to public awareness in this regard. On the other hand, death-related internet scans have reached the highest levels in March 2020, but they have been shown a decreasing trend since the begining of April. Searching of daily death number related with coronavirus has been in first place in both of countries, and also the number of deaths in Italy has been screened with a high volume in Turkey for five months. Lastly, although cholesterol related searches have always had high search volumes in the last one year, we have seen that it has significantly decreased in five-month period. In Turkey, the debate about cholesterol medications is often kept in the agenda, but discussions on cholesterol remain in the background due to the intense COVID-19 agenda. ${ }^{18}$ It can be noticed that there is a significant decrease in cholesterol screening due to the shift of the attention of the society in a different direction.

Taken together, this GTTM-based investigation provided new evidence for public interest. However, it should be noted that the intensity of the search is closely related to the fact that the subject is in written or visual media. The high mortality rates during the COVID-19 pandemic, quarantine practices in the countries, the behaviors de- 
veloped by the people in the quarantine process and the economic effects of the disease have created awareness about COVID-19 in almost all individuals. It has been speculated that GT ${ }^{\mathrm{TM}}$ can be used to detect success rates of awareness programs and predict infectious outbreaks worldwide. ${ }^{19}$ There has been a growing awareness of a disease that has never been seen before in the world in a short time. It can be thought that it attracted the attention of the society because of the disease rapid spread all over the world and causes rapid death in patients with risk factors. However, it should be kept in mind that this increased awareness may cause anxiety disorders and post-traumatic stress disorders in some people.

\section{Limitations}

This study has some limitations. First of all the study sample is unknown and demographical characteristic of population such as age, sex or comorbid disease (hypertension, coronary artery disease etc.) cannot be included in an analysis. Especially, knowing the number of deaths caused by acute coronary syndrome or number of patients with acute coronary syndromes, especially in the last five months, and making comparisons between previous years and the last five months could be more valuable to test the reliability of these large internet data.

\section{Conclusion}

COVID-19 outbreak has caused serious changes in social life. It may cause delay in admission to hospital due to the concern of COVID-19 transmission in the community. Information on public interest with using internet could be used to determine behaviours of people for searching several disease and their symptoms during the outbreak.

\section{Acknowledgements}

None.

\section{Conflict of interest}

None.

\section{Ethical statement}

Necessary permissions were obtained from the Ministry of Health of the Republic of Turkey.

\section{References}

1. Benjamin EJ, Muntner P, Alonso A, et al. Heart Disease and Stroke Statistics - 2019 Update: A Report From the American Heart Association. Circulation 2019;139:e56-e528.

2. Garcia S, Albaghdadi MS, Meraj PM, et al. Reduction in ST-Segment Elevation Cardiac Catheterization Laboratory Activations in the United States During COVID-19 Pandemic. J Am Coll Cardiol 2020;75:2871-2872.

3. Rodriguez-Leor O, Cid-Alvarez B. STEMI Care During COVID-19: Losing Sight of the Forest for the Trees. JACC Case Rep 2020;2:1625-1627.

4. De Filippo O, D'Ascenzo F, Angelini F, et al. Reduced Rate of Hospital Admissions for ACS during Covid-19 Outbreak in Northern Italy. N Engl J Med 2020;383:88-89.

5. Jellison SS, Bibens M, Checketts J, Vassar M. Using Google Trends to assess global public interest in osteoarthritis. Rheumatol Int 2018:38:2133-2136.

6. Cervellin G, Comelli I, Lippi G. Is Google Trends a reliable tool for digital epidemiology? Insights from different clinical settings. J Epidemiol Glob Health 2017;7:185-189.

7. Ginsberg J, Mohebbi MH, Patel RS, et al. Detecting influenza epidemics using search engine query data. Nature 2009;457:1012-1014.

8. Bousquet J, Agache I, Anto JM, et al. Google Trends terms reporting rhinitis and related topics differ in European countries. Allergy 2017;72:1261-1266.

9. Walker A, Hopkins C, Surda P. The use of Google Trends to investigate the loss of smell related searches during COVID-19 outbreak. Int Forum Allergy Rhinol 2020;10:839-847.

10. Effenberger $M$, Kronbichler $A$, Shin Jl, et al. Association of the COVID-19 pandemic with Internet Search Volumes: A Google Trends ${ }^{\top M}$ Analysis. Int J Infect Dis 2020;95:192-197.

11. Arora VS, McKee M, Stuckler D. Google Trends: Opportunities and limitations in health and health policy research. Health Policy 2019;123:338-341.

12. Mavragani A, Ochoa G. Google Trends in Infodemiology and Infoveillance: Methodology Framework. JMIR Public Health Surveill 2019;5:e13439.

13. Kumar N, Pandey A, Garg N, et al. Seasonal and Geographic Patterns in Seeking Cardiovascular Health Information: An Analysis of the Online Search Trends. Mayo Clin Proc 2018;93:1185-1190.

14. Nguyen T, Tran T, Luo W, et al. Web search activity data accurately predict population chronic disease risk in the USA. J Epidemiol Community Health 2015;69:693-699.

15. Senecal C, Widmer RJ, Lerman LO, Lerman A. Association of Search Engine Queries for Chest Pain With Coronary Heart Disease Epidemiology. JAMA Cardiol 2018;3:1218-1221.

16. Płatek $A E$, Sierdziński J, Krzowski B, Szymański FM. Trends in hypertension in Poland: evidence from Google search engine query data. Kardiol Pol 2018;76:637-641.

17. Aktoz M, Altay H, Aslanger E, et al. Türk Kardiyoloji Derneği Uzlaşı Raporu: COVID-19 Pandemisi ve Kardiyovasküler Hastalıklar Konusunda Bilinmesi Gerekenler. Turk Kardiyol Dern Ars 2020;48(Suppl):1-48.

18. Dincer G, Dincer ZS, Alsancak AD, et al. Patient compliance to statin treatment: how effective is the media? Türk Aile Hek Derg 2016;20:23-28.

19. McLean S, Lennon P, Glare P. Internet search query analysis can be used to demonstrate the rapidly increasing public awareness of palliative care in the USA. BMJ Support Palliat Care 2019;9:40-44. 